\title{
Detection of Hammondia heydorni-Like Organisms and Their Differentiation From Neospora caninum Using Random-Amplified Polymorphic DNA-Polymerase Chain Reaction
}

\author{
Author(s): C. Sreekumar, D. E. Hill , V. M. Fournet, B. M. Rosenthal , D. S. Lindsay , and J. P. Dubey \\ Source: Journal of Parasitology, 89(5):1082-1085. 2003. \\ Published By: American Society of Parasitologists \\ DOI: http://dx.doi.org/10.1645/GE-93R \\ URL: http://www.bioone.org/doi/full/10.1645/GE-93R
}

BioOne (www.bioone.org) is a nonprofit, online aggregation of core research in the biological, ecological, and environmental sciences. BioOne provides a sustainable online platform for over 170 journals and books published by nonprofit societies, associations, museums, institutions, and presses.

Your use of this PDF, the BioOne Web site, and all posted and associated content indicates your acceptance of BioOne's Terms of Use, available at www.bioone.org/page/terms_of_use.

Usage of BioOne content is strictly limited to personal, educational, and non-commercial use. Commercial inquiries or rights and permissions requests should be directed to the individual publisher as copyright holder. 
AND I. TADA. 1993. The expulsion of Echinostoma trivolvis: Worm kinetics and intestinal cytopathology in conventional and athymic BALB/c mice. Parasitology 106: 297-304.

- H. ICHIKAWA, AND B. FRIED. 1998. The immunosuppressive compound FK506 does not affect expulsion of Echinostoma trivolvis in $\mathrm{C} 3 \mathrm{H}$ mice. Parasitology Research 84: 519-521.

, K. FuKudA, AND B. FRIED. 1998. The expulsion of Echinostoma trivolvis caused by goblet cell hyperplasia in severe combined immunodeficient (SCID) mice. Parasite 5: 219-222.

IsHIKAWA, N. 1994. Histochemical characteristics of the goblet cell mucins and their role in defense mechanisms against Nippostrongylus brasiliensis infection in the small intestine of mice. Parasite Immunology 16: 649-654.

- Y. Horit, T. Oinuma, T. Suganuma, and Y. Nawa. 1994. Goblet cell mucins as the selective barrier for the intestinal helminths: $\mathrm{T}$ cell-independent alteration of goblet cell mucins by immunologically 'damaged' Nippostrongylus brasiliensis worms and its significance on the challenge infection with homologous and heterologous parasites. Immunology 81: 480-486.

Kook, J., Y. Nawa, S. H. LeE, AND J. Y. ChaI. 1998. Pathogenicity and lethality of a minute intestinal fluke, Neodiplostomum seoulense, to various strains of mice. Journal of Parasitology 84: 1178-1183.

Koyama, K., AND Y. ITO. 2000. Mucosal mast cell responses are not required for protection against infection with the murine nematode parasite Trichuris muris. Parasite Immunology 22: 13-20.

LEE, S. H., AND J. Y. ChAI. 2001. A review of Gymnophalloides seoi (Digenea: Gymnophallidae) and human infections in the Republic of Korea. Korean Journal of Parasitology 39: 85-118. , M. H. ChoI, M. SEO, AND J. Y. CHAI. 1995. Oysters, Crassostrea gigas, as the second intermediate host of Gymnophalloides seoi (Gymnophallidae). Korean Journal of Parasitology 33: 1-7.

, S. K. Park, M. Seo, S. M. Guk, M. H. Choi, and J. Y. Chai. 1997. Susceptibility of various species of animals and strains of mice to Gymnophalloides seoi infection and the effects of immu- nosuppression in $\mathrm{C} 3 \mathrm{H} / \mathrm{HeN}$ mice. Journal of Parasitology 83: 883886.

Miller, H. R. P., J. F. Huntley, and G. R. Wallace. 1981. Immune expulsion and mucous trapping during the rapid expulsion of Nippostrongylus brasiliensis from primed rats. Immunology 44: 419429.

-, AND W. F. H. JARRETT. 1971. Immune reactions in mucous membranes 1 . Intestinal mast cell response during helminth expulsion in the rat. Immunology 20: $277-288$.

Nawa, Y., N. Ishikawa, K. Tsuchiya, Y. Horit, T. Abe, A. I. Khan, B. B. Shi, H. Itoh, H. Ide, and F. UChiyama. 1994. Selective effector mechanisms for the expulsion of intestinal helminths. Parasite Immunology 16: 333-338.

Odaibo, A. B., N. Ø. Christensen, And F. M. A. Ukoli. 1989. Further studies on the population regulation in Echinostoma caproni infections in NMRI mice. Proceedings of the Helminthological Society of Washington 56: 192-198.

ONAH, D. N., AND Y. NAWA. 2000. Mucosal immunity against parasitic gastrointestinal nematodes. Korean Journal of Parasitology 38: 209-236.

Schimmer, B. P., AND K. L. PARKeR. 2001. Adrenocorticotropic hormone: Adrenocortical steroids and their synthetic analogs; inhibitors of the synthesis and actions of adrenocortical hormones. In The pharmacological basis of therapeutics, 10th ed., J. G. Hardman, L. E. Limbird, and A. G. Gilman (eds.). McGraw-Hill, New York, New York, p. 1649-1677.

SEO, M. 1998. Relationship between the susceptibility of mice to Gymnophalloides seoi infection and the responses of mucosal mast cells and goblet cells. Ph.D. Thesis. Graduate School, Seoul National University, Seoul, South Korea, 45 p.

Weinstein, M. S., AND B. FrIED. 1991. The expulsion of Echinostoma trivolvis and retention of Echinostoma caproni in the ICR mouse: Pathological effects. International Journal for Parasitology 21: 255257.

\section{Detection of Hammondia heydorni-Like Organisms and Their Differentiation From Neospora caninum Using Random-Amplified Polymorphic DNA-Polymerase Chain Reaction}

C. Sreekumar, D. E. Hill, V. M. Fournet, B. M. Rosenthal, D. S. Lindsay, ${ }^{\star}$ and J. P. Dubey, Animal Parasitic Diseases Laboratory, Animal and Natural Resources Institute, Agricultural Research Service, United States Department of Agriculture, Beltsville, Maryland 20705 ; * Center for Molecular Medicine and Infectious Diseases, Department of Biomedical Sciences and Pathobiology, Virginia-Maryland Regional College of Veterinary Medicine, Virginia Tech, 1410 Prices Fork Road, Blacksburg, Virginia 24061. e-mail: kumar@anri.barc.usda.gov

ABSTRACT: Neospora caninum and Hammondia heydorni are morphologically and phylogenetically related coccidians that are found in dogs. New diagnostic genetic loci, based on random-amplified polymorphic DNA-polymerase chain reaction (RAPD-PCR), were developed to aid in the detection of $H$. heydorni-like parasites and to discriminate them from $N$. caninum and other related coccidians of dogs. On the basis of the data obtained from 5 random decamers, H. heydorni (Manhattan-1) and $N$. caninum (NC1) were characterized by distinct banding patterns (similarity index $=0.068$ ). High-stringency PCR assays were developed from the sequences of 2 cloned bands (GenBank BZ592549 and BZ592593), uniquely amplified from $H$. heydorni. Interestingly, using these primers, PCR amplification was achieved only from 2 of the 5 isolates presumed to represent $H$. heydorni. The same result was obtained from these 5 isolates using a recently described PCR assay directed to the $H$. heydorni internal transcribed spacer-1. It is concluded that $H$. heydorni and $N$. caninum are genetically distinct and that such tools may be useful for more detailed characterization of the diversity of related parasites occurring in dogs.

Neospora caninum is a parasite of livestock and companion animals and is an important cause of bovine abortion in dairy cattle worldwide (Dubey, 1999). It is transmitted transplacentally, by the ingestion of infected tissues and by the ingestion of food and water contaminated with oocysts excreted in the feces of dogs. The domestic dog is the only known definitive host for $N$. caninum (McAllister et al., 1998). The role of the dog in the epidemiology of $N$. caninum is currently unclear because experimentally infected dogs excrete only a few oocysts and the parasite has been isolated only twice from naturally infected dogs (Basso et al., 2001; S̆lapeta, Modry et al., 2002). Furthermore, $N$. caninum oocysts resemble morphologically the oocysts of a related coccidian, Hammondia heydorni, and there is no simple method to distinguish them. Little is known about the life cycle of H. heydorni or whether additional Hammondia species occur that use dogs as their definitive host (Dubey et al., 2002; Schares et al., 2002; S̆lapeta, Modry et al., 2002).

Until recently, the only genetic locus characterized for $H$. heydorni was the 18S ribosomal DNA (Dubey et al., 2002). More genetic data are needed to determine how distinct $H$. heydorni and related species are from $N$. caninum and to differentiate among them. Recently, $H$. heydorni was discriminated from $N$. caninum using primers based on 
TABLE I. Hammondia heydorni isolates and their amplification results.

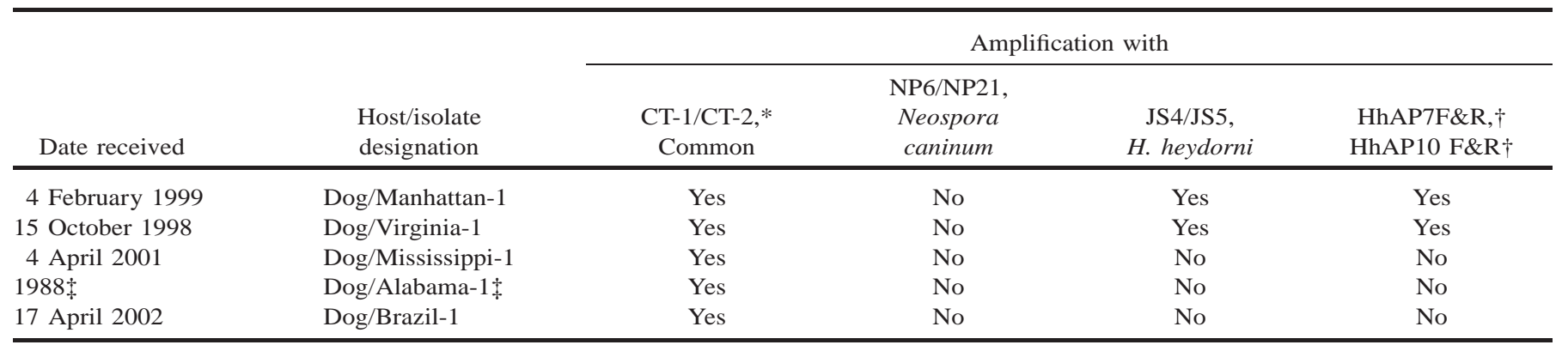

* Newly designed from ITS-1 sequences, amplifying DNA from Toxoplasma gondii, N. caninum, and Hammondia sp.

$\dagger$ Newly designed from the sequences of the polymorphic RAPD bands unique to H. heydorni.

$¥$ Blagburn et al. (1988) and Dubey et al. (2002).

the first internal transcribed spacer (ITS-1) sequences of ribosomal DNA (S̆lapeta, Koudela et al., 2002). The primers were designed from a region of the genome that is relatively conserved among many apicomplexans. Primers based on polymorphic sequences unique to $H$. heydorni may unequivocally differentiate it from $N$. caninum and provide an independent means of assessing genetic diversity among these related canine coccidia. An approach for studying DNA polymorphisms without the requirement of prior knowledge of the genome is the randomamplified polymorphic DNA-polymerase chain reaction (RAPD-PCR) (Welsh and McClelland, 1990; Williams et al., 1990). This technique uses single oligonucleotide primers at low stringency to produce polymorphic DNA. The patterns generated using this technique provide a rapid method for detecting genetic variation. Sequences obtained from individual polymorphic fragments thus generated can enable the design of primers for the PCR-based diagnosis and differentiation of closely related species under more stringent conditions, yielding reproducible results (Cere et al., 1996). In this study, we used RAPD-generated polymorphic fragments to design diagnostic primers to differentiate $H$. heydorni from $N$. caninum and used them to explore the genetic diversity among several canine coccidian isolates.

Information about the $H$. heydorni-like isolates used is given in Table I. These isolates were considered as $H$. heydorni based on the morphology of the oocysts (10.7 by $13.8 \mu \mathrm{m}, \mathrm{n}=50)$ and their inability to amplify the target fragment with $N$. caninum-specific primers (Table II). The NC1 isolate of $N$. caninum (Dubey et al., 1988) and the VEG strain of Toxoplasma gondii (Dubey et al., 1996) were maintained as tachyzoites in vitro in HCT-8 (ATCC CCL-244) cells. Isolates of Isospora canis, Nemeséri, 1959, Sarcocystis tenella (Railliet, 1886), Moule, 1886, and H. hammondi, Frenkel and Dubey, 1975 were available as sporocysts or sporulated oocysts.

To obtain DNA from H. heydorni, H. hammondi, S. tenella, and I. canis, sporulated oocyst or sporocyst suspensions were washed by repeated centrifugation in distilled water to remove the potassium dichromate. Each pellet was treated with $10-15 \mathrm{ml}$ of $5.25 \%$ sodium hypochlorite (on ice) to remove organic debris and then washed in water. The oocysts were ruptured by $2-3$ freeze-thaw cycles, followed by grinding of the pellet in small volumes (about $30 \mu \mathrm{l}$ ) in a $0.2-\mathrm{ml} \mathrm{mi-}$ crotissue grinder (Wheaton, Fischer Scientific, Pittsburgh, Pennsylvania). The DNA was extracted from the homogenized suspensions using DNAzol (MRC, Cincinnati, Ohio) according to the manufacturer's instructions. Toxoplasma gondii and N. caninum DNA were isolated using DNAzol from culture-derived tachyzoites. Canine DNA was isolated from the blood of an uninfected dog using the same procedure. The DNA preparations were suspended in distilled water and quantified spectrophotometrically (DU 640, Beckman, Fullerton, California).

Five random decamers (Table II) were used to investigate microhet-

TABLE II. Primers and PCR conditions.

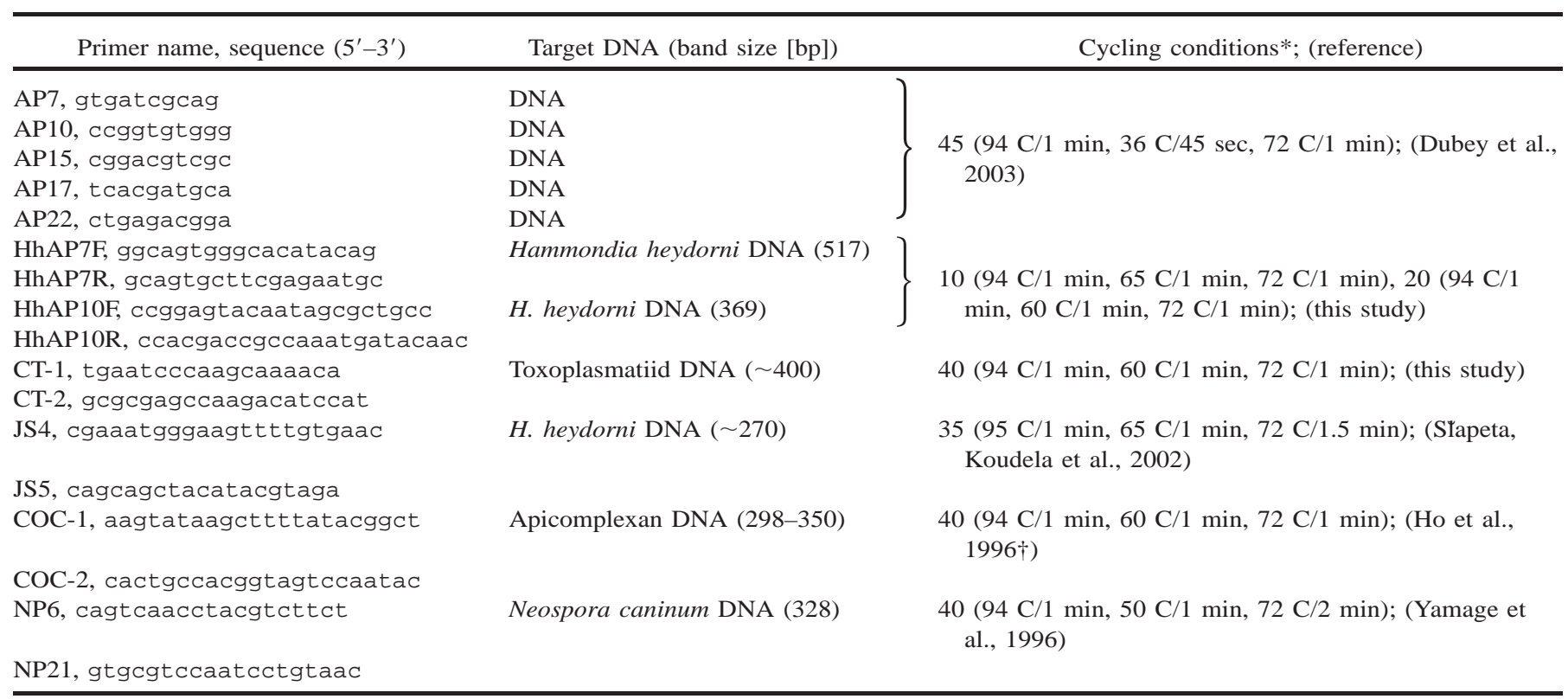

* An initial denaturation at $95 \mathrm{C}$ for $5 \mathrm{~min}$ and final extension at $72 \mathrm{C}$ for $5 \mathrm{~min}$ added to all protocols.

$\dagger$ Original PCR conditions modified. 


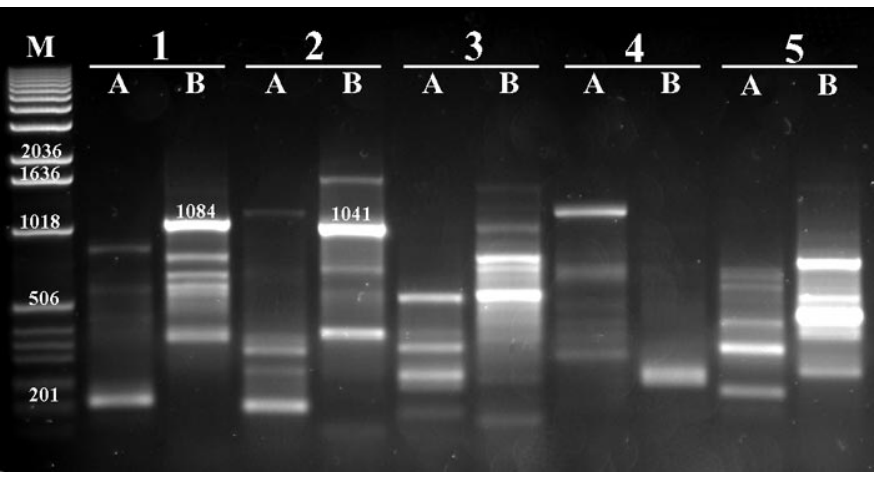

FIGURE 1. RAPD-PCR fingerprints of Neospora caninum (A) and Hammondia heydorni (B) with random primers AP7 (1), AP10 (2), AP15 (3), AP17 (4), and AP22 (5). Polymorphic fragments of 1,084 bp (1B) and $1,041 \mathrm{bp}(2 \mathrm{~B})$ were cloned and sequenced. $\mathrm{M}=1 \mathrm{~kb}$ DNA ladder (GIBCO BRL), Gaithersburg, Maryland.

erogenity between the isolates of $N$. caninum ( $\mathrm{NC} 1$ ) and $H$. heydorni (Manhattan-1). The Manhattan-1 isolate was chosen because of high oocyst count and apparent absence of other parasites. The RAPD-PCR reactions were set up in $25-\mu 1$ volumes in $0.2-\mathrm{ml}$ thin-walled PCR tubes as described by Dubey et al. (2003). The PCR assays were run 3 times to ensure reproducibility. Electrophoresis was performed at $5 \mathrm{~V} / \mathrm{cm}(90$ $100 \mathrm{~V})$ and documented using ProExpress Gel Documentation system (Perkin Elmer, Wellesley, Massachusetts). Data from each isolate-primer combination were combined, and the similarity coefficient between the isolates was calculated (Nei and Li, 1979).

Fragments unique in the RAPD fingerprint of $H$. heydorni DNA were selected for cloning and sequencing. The region of the gel containing the band was excised and placed in a microcentrifuge tube. The DNA was extracted from the gel piece using GFX PCR gel band purification kit (Amersham, Piscataway, New Jersey), reamplified using the origina random primer, and cloned into TOPO-TA vectors (Invitrogen, Carlsbad, California). The vectors were inserted into competent DH5 $\alpha$ cells (Invitrogen) and cultured overnight according to the manufacturer's instructions. Colonies with inserts were selected by blue-white differentiation, and white colonies were cultured overnight in Luria-Bertani broth at 37 C. Plasmids were extracted using QIAprep Spin Miniprep Kit (Qiagen, Valencia, California), and DNA was quantified. Sequencing reactions were performed using the Big Dye terminator system (Applied Biosystems, Foster City, California) and sequenced in an ABI 3100 sequencer. The sequence chromatograms were edited using Sequencher software (Genecodes Corp., Ann Arbor, Michigan). BLAST (http://www.ncbi.nlm.nih.gov/BLAST/) searches were performed to determine whether the sequences were similar to any of the previously published sequences of $H$. heydorni or any other parasite.

De novo primers were designed from the cloned RAPD products using the Gene Tool software program (Bio Tools Inc., Edmonton, Alberta, Canada). Primer pairs were optimized for amplification of the target fragments from $H$. heydorni DNA. To ascertain the specificity of these primers for $H$. heydorni, amplification was attempted from DNA of other apicomplexans (N. caninum, S. tenella, I. canis, T. gondii, and $H$. hammondi), canine DNA, and negative controls without any DNA. The quality of the H. heydorni DNA samples was verified using newly designed primers complementary to portions of the ITS-1 sequences conserved among $T$. gondii, $N$. caninum, and Hammondia sp. (Table II).

Experiments were conducted to determine the minimum amount of parasite DNA required to produce a visible band, using the newly designed PCR assays. PCR reactions were run, using serial 10-fold dilutions of DNA (representing 10,000 oocysts to 0.001 oocyst). The lowest number of oocyst(s) yielding a detectable band was considered to be the threshold level. For comparative purposes, the ITS-1 primers (Šlapeta, Koudela et al., 2002) were used under the same PCR conditions.

All 5 random primers produced DNA fingerprint patterns with both $N$. caninum and $H$. heydorni DNA (Fig. 1). The reproducible banding patterns were distinct for each template, with monomorphic fragments being amplified using only 2 primers. Of the 44 fragments amplified by

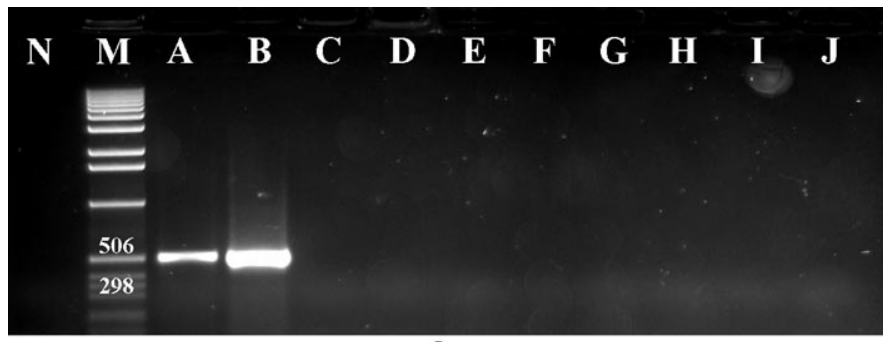

$\mathbf{a}$

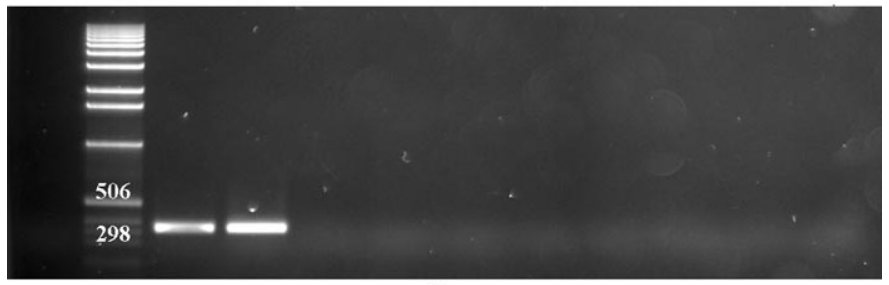

b

FIGURE 2. PCR with de novo primers HhAP7 (a) and HhAP10 (b) Specific amplification of 517-bp (a) and 369-bp (b) fragments noticed only with Hammondia heydorni DNA (lanes A and B). No amplification was noticed with negative control (N), Neospora caninum (C, D, and E), Sarcocystis tenella $(\mathrm{F})$, Isospora canis $(\mathrm{G})$, Toxoplasma gondii $(\mathrm{H})$, $H$. hammondi $(\mathrm{I})$, and canine DNA $(\mathrm{J}) . \mathrm{M}=1 \mathrm{~kb}$ DNA ladder (GIBCO BRL).

the 5 primers in total (21 for $N$. caninum and 23 for $H$. heydorni), only 3 (1 using primer AP7 and 2 using primer AP15) were shared. On the basis of the combined data from all the primers, a low similarity coefficient of 0.068 was established. The DNA fingerprint patterns generated by the 2 parasites in this study showed significant heterogeneity. The low similarity coefficient indicated that the parasites, although morphologically similar, were genetically distinct. It would be worthwhile to investigate the microheterogeneity among these parasites using a larger panel of random primers.

Two intense and reproducible bands of $\sim 1,000 \mathrm{bp}$ (designated henceforth as AP7 and AP10 fragments), amplified only from the H. heydorni DNA using primers AP7 and AP10, respectively, were selected for cloning and sequencing (GenBank BZ592549 [AP7] and BZ592593 [AP10]). The fragments bore no significant similarity to any published sequences for $H$. heydorni, $N$. caninum, or any other apicomplexan when the public database was queried with BLAST. Given the nature of distinct banding patterns between $N$. caninum and H. heydorni, it is

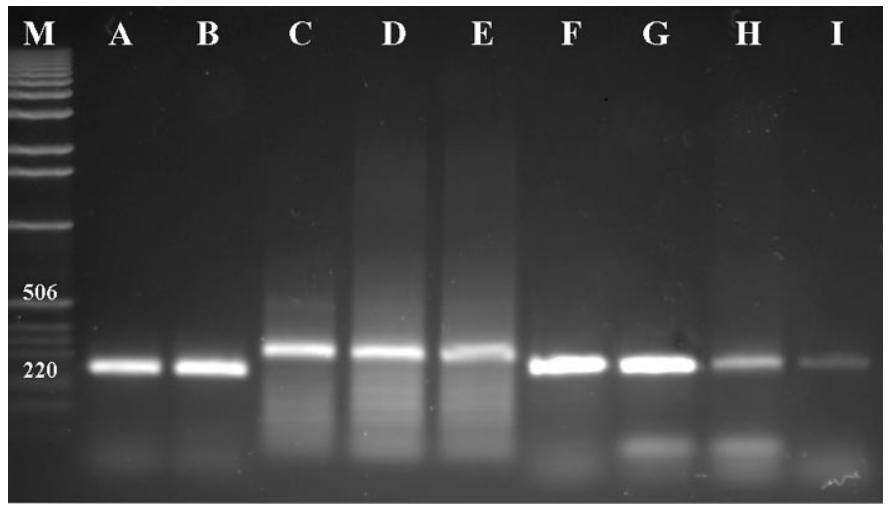

Figure 3. Amplification of 270-bp fragment from Hammondia heydorni (A-B), 328-bp fragment from Neospora caninum (lanes C, D, and E) and $~ 300-b p$ fragments from Sarcocystis tenella (F), Isospora canis (G), Toxoplasma gondii $(\mathrm{H})$, and $H$. hammondi (I) DNA using previously described primers (refer Table II). M $=1 \mathrm{~kb}$ DNA ladder (GIBCO BRL). 
possible that these fragments are unique to $H$. heydorni and can be valuable genetic markers for the unequivocal differentiation of $H$. heydorni from $N$. caninum. Such polymorphic fragments have been successfully used in the design of specific primer sets capable of differentiating other coccidians (Cere et al., 1996).

Two sets of primers were designed, 1 each from the AP7 fragment (HhAP7 forward and reverse) and AP10 fragment (HhAP10 forward and reverse). Under optimal thermal cycling conditions (Table II), a single amplification product was obtained from each assay. As estimated by their migration in an agarose gel, the fragments appeared to correspond to the sizes expected (517 and 369 bp for AP7 and AP10, respectively), based on their design (Fig. 2). The optimal $\mathrm{MgCl}_{2}$ concentration was determined to be $1 \mathrm{mM}$ for AP7 fragment and $1.25 \mathrm{mM}$ for the AP10 fragment.

The primers designed from the 2 fragments were found to specifically amplify the DNA from $2 \mathrm{H}$. heydorni isolates (Manhattan-1 and Virginia-1) obtained from dogs of 2 different localities in the United States (Fig. 2). No amplicon was produced from the templates of the other canine apicomplexans, the host DNA, or negative controls, providing evidence for specificity of the primers. The suitability of these other DNA samples as PCR templates was confirmed by the amplification of fragments of expected length using appropriate primer sets. Thus, whereas an amplicon of 328 bp was produced from the $N$. caninum DNA using the NP6/NP21 primer sets (Yamage et al., 1996), fragments of approximately $300 \mathrm{bp}$ were amplified using the common apicomplexan ssrRNA primers (Ho et al., 1996) from S. tenella and I. canis, T. gondii, and H. hammondi DNA (Fig. 3).

The sensitivity assays revealed that whereas the new primers could detect 100 oocysts, the ITS-1 primers were able to produce a signal with 1 oocyst in a $25-\mu 1$ reaction. It is possible that a large proportion of these oocysts was degraded, and thus the number of intact oocysts contributing to the template was much less than assumed. The threshold should be verified using high-quality DNA from fresh oocysts.

Effective amplification of the $\sim 400$-bp product was achieved from all the $5 \mathrm{H}$. heydorni DNA samples using the toxoplasmatiid ITS-1 primers, confirming the presence of an adequate amount of amplifiable template. The Manhattan-1 and Virginia-1 isolates, which gave positive results using the primers constructed herein, also tested positive using the previously published, H. heydorni-specific, ITS-1 primers (Fig. 3), confirming their identity as $H$. heydorni. However, no amplification was observed with the DNA of the other $3 H$. heydorni isolates using the de novo primers, $H$. heydorni ITS-1 primers, or the $N$. caninum-specific primers. Thus, the evidence suggests that these 3 isolates are neither $N$. caninum nor $H$. heydorni.

The results of amplification with the 5 pairs of primers (common toxoplasmatiid ITS-1, N. caninum-specific, H. heydorni-specific ITS1 , and $2 H$. heydorni-specific de novo primers) indicate that more than 1 Hammondia-like parasite might be present in dogs (Table I). It has been proposed that $H$. heydorni encompasses more than 1 species (Dubey et al., 2002). Results of PCR obtained using the 2 new primer pairs reported herein provide additional support for the genetic distinction between $H$. heydorni and $N$. caninum and suggest a greater diversity between the morphologically similar parasites presently grouped as $H$. heydorni. Further studies are warranted to elucidate the identity of these hitherto uncharacterized parasites.

We thank Gena Groner, Entomology Branch, Centers for Disease Control and Prevention, for her assistance with the sequencing.

\section{LITERATURE CITED}

Basso, W., L. Venturini, M. C. Venturini, D. E. Hill, O. C. H. KwoK, S. K. Shen, And J. P. Dubey. 2001. First isolation of Neospora caninum from the feces of a naturally infected dog. Journal of Parasitology 87: 612-618.
Blagburn, B. L., D. S. Lindsay, L. J. Swango, G. L. Pidgeon, and K. G. BRAUND. 1988. Further characterization of the biology of Hammondia heydorni. Veterinary Parasitology 27: 193-198.

Cere, N., J. F. Humbert, D. Licois, M. Corvione, M. Afanassieff, And N. Chanteloup. 1996. A new approach for the identification and the diagnosis of Eimeria media parasite of the rabbit. Experimental Parasitology 82: 132-138.

DubeY, J. P. 1999. Recent advances in Neospora and neosporosis. Veterinary Parasitology 84: 349-367.

, B. C. Barr, J. R. Barta, I. Bjerkas, C. Bjorkman, B. L. Blagburn, D. D. Bowman, D. Buxton, J. T. Ellis, B. Gottstein, A. Hemphill, D. E. Hill, D. K. Howe, M. C. Jenkins, Y. Kobayashi, B. Koudela, A. E. Marsh, J. G. Mattsson, M. M. McAllister, D. Modry, Y. Omata, C. A. Speer, A. J. Trees, A. Uggla, S. J. Upton, D. J. L. Williams, And D. S. Lindsay. 2002. Redescription of Neospora caninum and its differentiation from related coccidia. International Journal for Parasitology 32: 929-946.

, J. L. Carpenter, C. A. Speer, M. J. Topper, and A. Uggla. 1988. Newly recognized fatal protozoan disease of dogs. Journal of American Veterinary Medical Association 192: 1269-1285.

, J. K. Lunney, S. K. Shen, O. C. H. Kwok, D. A. Ashford, AND P. THULLIEZ. 1996. Infectivity of low numbers of Toxoplasma gondii oocysts to pigs. Journal of Parasitology 82: 438-443.

- , C. Sreekumar, D. S. Lindsay, D. E. Hill, B. M. Rosenthal, L. Venturini, M. C. Venturini, and E. C. Greiner. 2003. Besnoitia oryctofelisi n. sp. (Protozoa: Apicomplexa) from domestic rabbits. Parasitology 126: 521-539.

Ho, M. S. Y., B. C. BARr, A. E. Marsh, M. L. Anderson, J. D. Rowe, A. F. Tarantal, A. G. Hendrickx, K. Sverlow, J. P. Dubey, and P. A. Conrad. 1996. Identification of Neospora parasites by PCR amplification and small-subunit rRNA sequence probe hybridization. Journal of Clinical Microbiology 34: 1203-1208.

McAllister, M. M., J. P. Dubey, D. S. Lindsay, W. R. Jolley, R. A. Wills, AND A. M. MCGuire. 1998. Dogs are definitive hosts of Neospora caninum. International Journal for Parasitology 28: 1473-1478.

NEI, M., AND W. H. LI. 1979. Mathematical model for studying the variation in terms of restriction endonucleases. Proceedings of the National Academy of Science of the United States of America 76: 5269-5273.

Schares, G., A. O. Heydorn, A. Cüppers, H. Mehlhorn, L. Geue, M Peters, And F. J. ConRATHs. 2002. In contrast to dogs, red foxes (Vulpes vulpes) did not shed Neospora caninum upon feeding of intermediate host tissues. Parasitology Research 88: 44-52.

S̆lapeta, J. R., B. Koudela, J. Votypka, D. Modry, R. Horejs, and J. LUKES. 2002. Coprodiagnosis of Hammondia heydorni in dogs by PCR based amplification of ITS 1 rRNA: Differentiation from morphologically indistinguishable oocysts of Neospora caninum. Veterinary Journal 163: 147-154.

, D. Modry, I. Kyselova, R. Horejs, J. Lukes, And B. KouDELA. 2002. Dog shedding oocysts of Neospora caninum: PCR diagnosis and molecular phylogenetic approach. Veterinary Parasitology 109: 157-167.

Welsh, J., AND M. MCClelland. 1990. Fingerprinting genomes using PCR with arbitrary primers. Nucleic Acids Research 18: 72137218.

Williams, J. G. K., A. R. Kubelik, K. J. Livak, J. A. Rafalski, and S. V. TINGEY. 1990. DNA polymorphisms amplified by arbitrary primers are useful as genetic markers. Nucleic Acids Research 18: 6531-6535.

Yamage, M., O. Flechtner, And B. Gottstein. 1996. Neospora caninum: Specific oligonucleotide primers for the detection of brain "cyst" DNA of experimentally infected nude mice by the polymerase chain reaction (PCR). Journal of Parasitology 82: 272-279. 